\title{
Long-Term Study of Toxoplasma gondii Infection in a Swedish Sheep Flock
}

\author{
By A. Lundén ${ }^{1}, A$. Näsholm ${ }^{2}$ and $A$. Uggla ${ }^{1}$ \\ ${ }^{1}$ Department of Parasitology, Swedish University of Agricultural Sciences and National Veterinary Institute, \\ and ${ }^{2}$ Department of Animal Breeding and Genetics, Swedish University of Agricultural Sciences, Uppsala, \\ Sweden.
}

\begin{abstract}
Lundén, A., A. Näsholm and A. Uggla: Long term study of Toxoplasma gondii infection in a Swedish sheep flock. Acta vet. scand. 1994, 35, 273-281. - The infection rate of Toxoplasma gondii was studied during 6 years in a sheep flock in central Sweden. The flock consisted of $165-249$ breeding ewes of which $20-35 \%$ were lambs less than 1 year old. Most ewes were slaughtered when 5 years old. The sheep were kept indoors from end of September to early May. Lambing took place in March and April. Individual serum samples were collected twice a year, once just before turning the sheep out to pasture in the spring, and again after housing in the autumn. Sera were analysed by ELISA for antibodies to $T$. gondii. The seroprevalence varied between $10 \%$ and $45 \%$ during the 6 years of observation. Seroconversion was detected predominantly at the autumn sampling, indicating that in most cases infection was acquired at pasture. Subclinical effects of $T$. gondii infection on lamb weight, litter size, total litter weight and ewe weight were also studied. Lambs born to chronically infected ewes were lighter at birth than those of uninfected ewes, but this disparity was no longer evident at weaning.
\end{abstract}

toxoplasmosis; ELISA; epidemiology; seroprevalence; incidence; production traits.

\section{Introduction}

The protozoan parasite Toxoplasma gondii is regarded in many countries as one of the most important causes of infectious abortion and neonatal mortality in sheep. In non-immune ewes, an infection acquired during pregnancy may spread to the placenta and fetus, and cause abortion, stillbirth or delivery of weak, infected lambs. After the acute stage of infection, the parasites establish as cysts containing dormant organisms in various tissues, and a lifelong, persistent infection develops. This chronic stage is associated with a strong immunity and a reinfection in subsequent pregnancies will not result in transmission to the fetus. Infection of non-pregnant sheep does not cause any symptoms, or only mild ones (Dubey \& Towle 1986).

Since only a primary infection during pregnancy may result in fetal damage, it is of interest to ascertain when and where sheep are likely to become infected. Sheep pick up the parasite by ingesting feed or water contaminated with oocysts shed in the feces of cats, the final host of the organism. These oocysts are remarkably hardy and have been found to survive for prolonged periods in the environment. Since their survival is dependent on temperature and humidity, where they are deposited is decisive (Frenkel et al. 1975). Consequently, the risk of exposure of susceptible 
sheep to infective oocysts is likely to be influenced by climate and weather conditions, as well as by farm management.

The aim of this work was to study the rate of T. gondii infection during a 6-year period in a Swedish sheep flock. In order to investigate whether persistent $T$. gondii infection may affect the performance of ewes, the effect of the infection on various production traits was also studied.

\section{Materials and methods}

Animals and management

The study was performed in the research flock of the Department of Animal Breeding and Genetics, Swedish University of Agricultural Sciences, located at the Funbo-Lövsta Research Station, Uppsala. The sheep were of the Swedish Finewool Landrace breed and the management of the flock was principally in accordance with traditional Swedish husbandary practices.

During the observation period, the number of breeding ewes varied between 165 and 249 . For replacements 45-60 ewe lambs were mated each year. During 1985-87 most ewes were culled when 5 years old. In the autumn of 1988 the flock was expanded by mating a total of 90 ewe lambs. From then and onwards, $10-20 \%$ of the flock consisted of ewes older than 5 years.

The structure of the flock was designed to allow for studies of fundamental biological and genetic relationships. To avoid bias from selection, rams and ewes were recruited at random and ewes were not culled because of low production capacity. Thus barren ewes were mated again the following season, while ewes affected by traumatic injury or disease, such as mastitis, were slaughtered. Rams were recruited from other flocks and were unrelated to each other. The structure of the flock, as well as management and feeding routins and registration methods are described in detail by Näsholm \& Danell (1990). The herd also included ewes that were not involved in the genetic studies, and for which registrations of reproductive performance and lamb weights were not done. These ewes were examined serologically for antibodies to $T$. gondii, but were not included in the analyses of influence on production performance.

The sheep were housed from the end of September or early October to early May. They were kept on straw bedding, and fed hay and concentrate according to the Swedish standard feeding norm. The mating period lasted from about October 15 to December 20 and the ewes lambed in March and April. At pasture, the sheep were divided into 2-4 groups grazing at 5 different locations (A-E) situated 3-15 km apart. After weaning in mid-July, lambs and ewes grazed on separate pastures. The allocation of the individual ewes to different pastures after turn-out was recorded, but information about which animals used which pastures after weaning is incomplete. The dates of turning out and housing each year are shown in Table 1.

Cats were kept on the Research Station for rodent control, and all pastures were in the vicinity of farm buildings and/or human dwellings and therefore likely to be frequented by cats. However, detailed information on the cat population was not available.

During the observation period the annual incidences of barrenness, abortion and stillbirth in the flock were $2.7-10.9 \%, 0-1.7 \%$ and $4.6-7.6 \%$, respectively.

\section{Blood sampling}

Blood samples were collected from all ewes older than 5 months, twice a year from 1985 until 1990, just before turn-out and again after housing. Days of sampling and numbers of samples analysed on each occasion are shown 
Table 1. Seroprevalence and incidence of Toxoplasma gondii infection in a Swedish sheep flock during a 6year observation period. Individual serum samples were analysed by ELISA twice a year. At each autumn sampling, 20-35\% of the flock consisted of 6-month-old lambs not sampled previously.

\begin{tabular}{|c|c|c|c|c|c|c|c|c|c|c|c|c|}
\hline $\begin{array}{l}\text { Sampling } \\
\text { date }^{\mathrm{a}}\end{array}$ & $\begin{array}{c}1985 \\
9 / 5\end{array}$ & $\begin{array}{l}1985 \\
3 / 12\end{array}$ & $\begin{array}{l}1986 \\
29 / 4\end{array}$ & $\begin{array}{r}1986 \\
20 / 11\end{array}$ & $\begin{array}{c}1987 \\
4 / 5\end{array}$ & $\begin{array}{c}1987 \\
20 / 10\end{array}$ & $\begin{array}{c}1988 \\
2 / 5\end{array}$ & $\begin{array}{c}1988 \\
26 / 10\end{array}$ & $\begin{array}{l}1989 \\
25 / 4\end{array}$ & $\begin{array}{l}1989 \\
5 / 10\end{array}$ & $\begin{array}{l}1990 \\
25 / 4\end{array}$ & $\begin{array}{c}1990 \\
19 / 10\end{array}$ \\
\hline $\begin{array}{l}\text { Turn-out or } \\
\text { housing }\end{array}$ & $13 / 5$ & $27 / 9$ & $14 / 5$ & $25 / 9$ & $4 / 5$ & $29 / 9$ & $5 / 5$ & $6 / 10$ & $3 / 5$ & $26 / 9$ & $4 / 5$ & $15 / 10$ \\
\hline No. of samples & 165 & 179 & 172 & 185 & 173 & 188 & 185 & 249 & 202 & 177 & 190 & 235 \\
\hline Prevalence (\%) & 30 & 18 & 18 & 10 & 12 & 16 & 15 & 30 & 31 & 28 & 27 & 45 \\
\hline Seroconversion $^{c}$ & - & 9 & 0 & 1 & 0 & 15 & 1 & 48 & 4 & 3 & 0 & 56 \\
\hline $\begin{array}{l}\text { Monthly incidence } \\
(\%)^{d}\end{array}$ & - & 0.85 & 0 & 0.09 & 0 & 1.57 & 0.10 & 3.73 & 0.46 & 0.43 & 0 & 5.19 \\
\hline
\end{tabular}

a Year, day/month,

b Day/month.

c No. of ewes found seropositive for the first time.

dNo. of seroconversions/(no. initially seronegative ewes $\mathrm{x}$ months since last sampling).

in Table 1. Altogether 2,300 samples were analysed. Due to misreading or loss of ear-tags and/or wrongly labelled test tubes, 140 (5.7\%) sera had to be excluded. Sera were stored at $-20^{\circ} \mathrm{C}$ until analysed.

\section{Serology}

Sera were analysed for antibodies to $T$. gondii by ELISA as described previously (Lundén et al. 1992). Soluble T. gondii antigen (National Bacteriological Laboratory, Stockholm, Sweden) was used as coating antigen and horseradish peroxidase conjugated rabbit antisheep immunoglobulin (Dakopatts, Copenhagen, Denmark) as secondary antibody. All sera were analysed in duplicate at 1:400 dilution, and those with an absorbance value $\left(\mathrm{A}_{450}\right)$ exceeding 0.20 were deemed positive. $\left(0.20=\right.$ mean $\mathrm{A}_{450}+3$ standard deviations of 41 sheep sera negative to $T$. gondii in both the indirect fluorescent antibody test (Uggla \& Hjort 1984) and the direct agglutination test
(Desmonts \& Remington 1980).) One negative and two positive control sera were included on each plate. The negative control was a pool of three sera previously tested negative, and the positive sera were from two naturally infected sheep.

Sera with an absorbance value close to the cut-off level were also tested with the direct agglutination test, for which a commercial kit (Toxoscreen DA, BioMérieux, Marcyl'Etoile, France) was used. Since in this assay, high levels of antibodies may result in a false negative reaction at low serum dilutions, the sera were analysed at 1:40 and 1:4000 dilutions. Sera were deemed positive if a positive reaction, i.e. the antigen agglutinated in a mat covering about half of the well base, was observed at one or both dilutions tested (Desmonts \& Remington 1980).

\section{Statistical analyses}

Comparison of infection rate on dif- 
Table 2. Number of observations for various traits associated with uninfected, chronically infected and recently infected ewes.

\begin{tabular}{lcccc}
\hline Trait & $\begin{array}{c}\text { No } \\
\text { infection }\end{array}$ & $\begin{array}{c}\text { Chronic } \\
\text { infection }\end{array}$ & $\begin{array}{c}\text { Recent } \\
\text { infection }\end{array}$ & Total \\
\hline Litter size at birth & 593 & 169 & 1 & 763 \\
Litter size at weaning & 432 & 131 & 66 & 629 \\
Lamb weight at birth & 1316 & 394 & 2 & 1712 \\
Lamb weight at weaning & 967 & 302 & 138 & 1407 \\
Total litter weight at birth & 593 & 169 & 1 & 763 \\
Total litter weight at weaning & 432 & 131 & 66 & 629 \\
Weight of ewe at lambing & 499 & 103 & 1 & 603 \\
Weight of ewe at weaning & 369 & 70 & 40 & 479 \\
\hline
\end{tabular}

a Seroconversion was recorded during the latest observation period.

ferent pastures. Significance of differences in incidence rate between groups of sheep grazing on different pastures were assessed with the Chi-square test.

Influence of infection on production traits. Analyses of variance were performed to test the effect of the ewe being infected or not on litter size at birth and at weaning, individual weight of lambs at birth and when 120 days old, total litter weight per ewe at birth and at weaning, and on weight of ewe one day after lambing and at weaning. The GLM procedure available in the SAS statistical package (SAS Institute Inc. 1985) was used for these analyses. The data consisted of records from a total of 603 ewes and 1858 lambs during 1985-1990. Ewe weights were not recorded in 1989 and 1990 . The number of observations for each combination of production trait and infection status is presented in Table 2. Infection status was defined as uninfected (seronegative), recently infected (seroconversion since last sampling), or chronically infected (seropositive). For traits recorded at lambing, infection status as observed just before turn-out in the spring was used, while serological results obtained after housing in the autumn were utilized for traits recorded at weaning and lamb weight at 120 days of age. Since the autumn sampling usually was done after the culling of ewes that were not selected for breeding next year, the number of observations for traits recorded at weaning and at 120 days of age are fewer than those recorded at lambing.

For litter size and total litter weight per ewe at birth and at weaning, the following model was used:

(model 1)

$\mathrm{Y}_{\mathrm{ijklm}}=\mu+\mathrm{q}_{\mathrm{i}}+\mathrm{a}_{\mathrm{j}}+\mathrm{z}_{\mathrm{k}}+\mathrm{s}_{\mathrm{kl}}+\mathrm{e}_{\mathrm{ijklm}}$

where

$\mathrm{Y}_{\mathrm{ijklm}}=$ observed litter size or total lamb weight

$\mu \quad=$ overall mean

$\mathrm{q}_{\mathrm{i}} \quad=$ fixed effect of $i$ th status of infection, $i=1,3$

$\mathrm{a}_{\mathrm{j}} \quad=$ fixed effect of $j$ th age of ewe, $j=1,6$

$\mathrm{z}_{\mathrm{k}} \quad=$ fixed effect of $k$ th year, $k=1,6$

$\mathrm{s}_{\mathrm{kl}} \quad=$ random effect of $l$ th sire nested within $k$ th year $\mathrm{N}\left(0, \sigma_{\mathrm{s}}^{2}\right)$

$\mathrm{e}_{\mathrm{ijklm}}=$ random residual effect $\mathrm{N}\left(0, \sigma_{\mathrm{e}}^{2}\right)$

For lamb weight at birth and at weaning, the following model was used: 
(model 2)

$\mathrm{Y}_{\mathrm{ijklmno}}=\mu+\mathrm{q}_{\mathrm{i}}+\mathrm{a}_{\mathrm{j}}+\mathrm{z}_{\mathrm{k}}+\mathrm{k}_{1}+\mathrm{r}_{\mathrm{m}}+\mathrm{s}_{\mathrm{kn}}+\mathrm{e}_{\mathrm{ijk} \mathrm{kmno}}$

where $\mu, \mathrm{q}_{\mathrm{i}}, \mathrm{a}_{\mathrm{j}}$ and $\mathrm{z}_{\mathrm{k}}$ are the same as in model 1 and

$\mathrm{Y}_{\mathrm{ijklmno}}=$ observed lamb weight

$\mathrm{k}_{\mathrm{l}} \quad=$ fixed effect of $k$ th sex of lamb, $k=1,2$

$\mathrm{r}_{\mathrm{m}} \quad=$ fixed effect of $m$ th litter size, $m=1,5$

$\mathrm{s}_{\mathrm{kn}} \quad=$ random effect of $n$th sire nested within $k$ th year $\mathrm{N}\left(0, \sigma_{\mathrm{s}}^{2}\right)$

$\mathrm{e}_{\mathrm{ijklmno}}=$ random residual effect $\mathrm{N}\left(0, \sigma_{\mathrm{e}}^{2}\right)$

For ewe weight one day after lambing and at weaning, the following model was used:

$\mathrm{Y}_{\mathrm{ijkl}}=\mu+\mathrm{q}_{\mathrm{i}}+\mathrm{a}_{\mathrm{j}}+\mathrm{z}_{\mathrm{k}}+\mathrm{e}_{\mathrm{ijkl}} \quad(\operatorname{model} 3)$

where $\mu, \mathrm{q}_{\mathrm{i}}$ and $\mathrm{a}_{\mathrm{j}}$ are the same as in model 1 and

$\mathrm{Y}_{\mathrm{ijkl}} \quad=$ observed ewe weight

$\mathrm{z}_{\mathrm{k}} \quad=$ fixed effect of $k$ th year, $k=1,4$

$\mathrm{e}_{\mathrm{ijkl}} \quad=$ random residual effect $\mathrm{N}\left(0, \sigma_{\mathrm{e}}^{2}\right)$

As sire was treated as nested within year, sires that had observations from 2 years were excluded from the analyses the last year.

\section{Results}

\section{Seroprevalence and infection rate}

In May 1985 when the study started, antibodies to $T$. gondii were detected in sera from $30 \%$ of the ewes. During the subsequent 18 months, the seroprevalence decreased to $10 \%$, and then gradually increased to reach $45 \%$ on the last sampling occasion, in October 1990. A total of 143 sheep (including 32 ewe lambs found seropositive when tested at approximately 6 months of age) turned seropositive during the observation period. The increase in absorbance value was on average
0.68 ranging from 0.29 to 1.59 . In cases were the increase was relatively small, seroconversion was confirmed or excluded by the direct agglutination test. In 132 of the 143 sheep, seroconversion was detected after housing in the autumn while only 5 ewes appeared to have been infected during the winter. For the remaining 6 , the serum collected prior to the first positive sample was missing. One of the 32 seropositive lambs was born to a ewe which became seropositive while pregnant, indicating that this lamb could have been infected in utero. Two of the lambs were born to ewes tested positive previously and 2 by mothers not tested that spring, while 27 had seronegative mothers. The incidence rate varied considerably over the 6-year observation period, and was highest in the summers of 1988 and 1990 (Table 1). Although the seroprevalence increased with age, the incidence rate was similar in different age groups (data not shown) except that during the summer of 1990 it was significantly lower in lambs than in ewes (see below).

In 1988 when the sheep were grazing at two different locations (A and B), 33 (45\%) of 74 initially seronegative sheep seroconverted on pasture A, while on pasture B only $8(9 \%)$ of 86 seroconverted. The difference was statistically highly significant $(\mathrm{p}<0.001)$. The next year (1989), when only one ewe seroconverted, pastures $\mathrm{A}, \mathrm{C}$ and $\mathrm{D}$ were used. In 1990 the ewes were divided into 4 groups, which after turn-out grazed on pastures A, B, $\mathrm{C}$ and $\mathrm{E}$, respectively. After weaning all lambs were put on pasture $C$, the ewes on pasture $B$, $\mathrm{C}$, and $\mathrm{E}$ were kept on pasture $\mathrm{B}$, while the ewes on pasture A remained on that pasture. The seroconversion rates were similar in the 4 initial groups (33-44\%). Altogether 53 (39\%) of 136 ewes turned seropositive, whereas only $3(6 \%)$ of 50 lambs seroconverted. This difference was highly significant statistically 
Table 3. Analyses of variance for observed traits.

\begin{tabular}{|c|c|c|c|c|}
\hline $\begin{array}{l}\text { Source of } \\
\text { variation }\end{array}$ & $\begin{array}{c}\text { Degrees } \\
\text { of freedom }\end{array}$ & $\begin{array}{l}\text { Mean }^{\mathrm{a}} \\
\text { squares }\end{array}$ & $\begin{array}{c}\text { Degrees } \\
\text { of freedom }\end{array}$ & $\begin{array}{l}\text { Mean }^{a} \\
\text { squares }\end{array}$ \\
\hline & \multicolumn{2}{|c|}{ Litter size at birth } & \multicolumn{2}{|c|}{ Litter size at weaning } \\
\hline Status of infection & 2 & $0.71^{\mathrm{NS}}$ & 2 & $0.39^{\mathrm{NS}}$ \\
\hline Age of ewe & 5 & $16.86^{* * *}$ & 5 & $10.29 * * *$ \\
\hline Year & 5 & $2.30 *$ & 5 & $0.29^{\mathrm{NS}}$ \\
\hline Sire & 50 & $0.71^{\mathrm{NS}}$ & 50 & $0.67^{\mathrm{NS}}$ \\
\hline \multirow[t]{3}{*}{ Error } & 700 & 0.57 & 566 & 0.55 \\
\hline & & $\mathrm{R}^{2}=0.26$ & & $\mathrm{R}^{2}=0.23$ \\
\hline & \multicolumn{2}{|c|}{ Lamb weight at birth } & \multicolumn{2}{|c|}{ Lamb weight at 120 days } \\
\hline Status of infection & 2 & $1.67 *$ & 2 & $45.02^{\mathrm{NS}}$ \\
\hline Age of ewe & 5 & $20.73 * * *$ & 5 & $807.23 * * *$ \\
\hline Year & 5 & $3.80 * *$ & 5 & $268.63^{* * *}$ \\
\hline Sex of lamb & 1 & $18.30 * * *$ & 1 & $3025.96 * * *$ \\
\hline Litter size & 4 & $57.33^{* * *}$ & 4 & $2264.99 * * *$ \\
\hline Sire & 52 & $1.12 * * *$ & 51 & $53.46^{* * *}$ \\
\hline \multirow[t]{3}{*}{ Error } & 1642 & 0.37 & 1338 & 19.62 \\
\hline & & $\mathrm{R}^{2}=0.37$ & & $\mathrm{R}^{2}=0.43$ \\
\hline & \multicolumn{2}{|c|}{ Total litter weight at birth } & \multicolumn{2}{|c|}{ Total litter weight at weaning } \\
\hline Status of infection & 2 & $10.73^{\mathrm{NS}}$ & 2 & $20.60^{\mathrm{NS}}$ \\
\hline Age of ewe & 5 & $261.75^{* * *}$ & 5 & $13566.93^{* * *}$ \\
\hline Year & 5 & $19.65^{\mathrm{NS}}$ & 5 & $561.88^{\mathrm{NS}}$ \\
\hline Sire & 50 & $9.54 * * *$ & 50 & $517.65^{\mathrm{NS}}$ \\
\hline \multirow[t]{3}{*}{ Error } & 700 & 4.69 & 566 & 387.24 \\
\hline & & $\mathrm{R}^{2}=0.38$ & & $\mathrm{R}^{2}=0.32$ \\
\hline & \multicolumn{2}{|c|}{ Weight of ewe at lambing } & \multicolumn{2}{|c|}{ Weight of ewe at weaning } \\
\hline Status of infection & 2 & $25.57^{\mathrm{NS}}$ & 2 & $48.36^{\mathrm{NS}}$ \\
\hline Age of ewe & 5 & $4354.67 * * *$ & 5 & $2486.91 * * *$ \\
\hline Year & 3 & $137.88^{*}$ & 3 & $62.63^{\mathrm{NS}}$ \\
\hline \multirow[t]{2}{*}{ Error } & 592 & 44.14 & 468 & 44.45 \\
\hline & & $\mathrm{R}^{2}=0.48$ & & $\mathrm{R}^{2}=0.38$ \\
\hline
\end{tabular}

${ }^{* * *} \mathrm{p} \leq 0.001 ;{ }^{* *} \mathrm{p} \leq 0.01 ;{ }^{*} \mathrm{p} \leq 0.05 ;$ NS (non-significant) $\mathrm{p}>0.05$.

${ }^{\text {a }}$ According to SAS type III.

$(\mathrm{p}<0.001)$, indicating that infection occurred mainly after weaning on pastures $\mathrm{A}$ and $\mathrm{B}$. For the grazing periods $1985-87$, no association was found between pastures used and incidence of infection in the different groups. There was no significant difference between uninfected and chronically infected ewes as regards incidence of barrenness and stillbirth. During the observation period 9 seronegative ewes aborted. No seroconversion was de- tected in association with these abortions. The 5 ewes that seroconverted in the winter each gave birth to 1-3 healthy lambs. One of these was kept as a replacement and had antibodies to $T$. gondii when tested at 6 months of age in the autumn.

\section{Influence on production traits}

Table 3 presents the analysis of variance for the various traits, and in Table 4 least squares 
Table 4. Least squares means \pm standard errors for observed traits associated with uninfected, chronically infected and recently infected ewes.

\begin{tabular}{lrrr}
\hline Trait & $\begin{array}{c}\text { No } \\
\text { infection }\end{array}$ & $\begin{array}{c}\text { Chronic } \\
\text { infection }\end{array}$ & $\begin{array}{c}\text { Recent } \\
\text { infection }\end{array}$ \\
\hline Litter size at birth & $2.6 \pm 0.0$ & $2.5 \pm 0.1^{\mathrm{c}}$ & $3.2 \pm 0.8^{\mathrm{c}}$ \\
Litter size at weaning & $2.4 \pm 0.0$ & $2.3 \pm 0.1^{\mathrm{c}}$ & $2.3 \pm 0.1^{\mathrm{c}}$ \\
Lamb weight at birth, kg & $3.5 \pm 0.0$ & $3.4 \pm 0.0^{\mathrm{a}}$ & $4.0 \pm 0.5^{\mathrm{c}}$ \\
Lamb weight at 120 days, kg & $30.5 \pm 0.3$ & $30.7 \pm 0.4^{\mathrm{c}}$ & $31.4 \pm 0.5^{\mathrm{b}}$ \\
Total litter weight per ewe at birth, kg & $9.0 \pm 0.1$ & $8.5 \pm 0.2^{\mathrm{b}}$ & $9.8 \pm 2.3^{\mathrm{c}}$ \\
Total litter weight per ewe at weaning, kg & $75.4 \pm 1.2$ & $74.8 \pm 1.9^{\mathrm{c}}$ & $75.7 \pm 2.8^{\mathrm{c}}$ \\
Weight of ewe at lambing, kg & $59.9 \pm 0.7$ & $59.2 \pm 0.9^{\mathrm{c}}$ & $64.7 \pm 6.7^{\mathrm{c}}$ \\
Weight of ewe at weaning, $\mathrm{kg}$ & $58.1 \pm 0.9$ & $57.5 \pm 1.0^{\mathrm{c}}$ & $59.5 \pm 1.4^{\mathrm{c}}$ \\
\hline
\end{tabular}

a The least squares mean differed significantly from that of non-infected ewes ( $\leq \leq 0.01)$.

b The least squares mean differed significantly from that of non-infected ewes $(\mathrm{p} \leq 0.05)$.

c The least squares mean did not differ significantly from that of non-infected ewes $(\mathrm{p}>0.05)$.

means for the traits are presented according to status. No negative effect of $T$. gondii infection on litter size or ewe weight was found. However, there did appear to be an effect on birth weight. Least squares means for individual lamb weights and total litter weight per ewe were significantly lower in chronically infected than in uninfected ewes ( $\mathrm{p} \leq 0.01$ and $\mathrm{p}$ $\leq 0.05$, respectively; Table 4). At weaning, no effect on lamb weight could be detected.

In the recently infected ewes, no negative effect of infection was observed on any of the production traits tested. As shown in Table 2, ewes recently infected at lambing were very few (1 or 2 ). This explains the high standard errors of the least squares means for these ewes.

\section{Discussion}

The prevalence of to $T$. gondii infection in sheep has been studied in numerous serological surveys conducted in different parts of the world. Results vary considerably, from 0 to $96 \%$ seropositive, with a median prevalence of 30\% (Blewett 1983). In Sweden, Uggla and Hjort (1984) found a seroprevalence of 60-70\%, while Lundén et al. (1992) detected antibodies to T. gondii in $19 \%$ of the sheep tested. In the latter study, the seroprevalence found in individual flocks varied between 0 and $78 \%$. Considering these differences, the results of the present investigations showing that the seroprevalence in a single flock can vary considerably between different sampling occations, are interesting. During the 6-year observation period the prevalence of antibodies to $T$. gondii varied from 10 to $45 \%$. These fluctuations were partly due to replacement of older ewes with lambs, which were mainly uninfected, and partly to infection, which occurred with great variations in incidence rate. The results obtained indicate that in the particular sheep flock studied, infection with T. gondii was acquired principally at pasture. Serological analyses twice a year revealed that seroconversion occurred predominantly in the summer. However, since there were considerable delays between housing and the autumn sampling in the first 4 years, 1985-88, infection after housing cannot be ruled out. Also, since the lambs were tested for the first time in the autumn, when about 6 months old, infection in lambs before turn-out could not be distinguished from infection at pasture. On 
the other hand, when comparing the incidence rates of sheep grazing on two different pastures in the summer of 1988, a significant difference was found between the two groups (45\% and $9 \%$, respectively). Furthermore, in 1990 a significantly higher incidence rate was observed in ewes than in lambs $(39 \%$ and $6 \%$, respectively) indicating that the source of infection was present on the pastures used for the ewes after weaning. These observations strengthen the assumption that infection was contracted predominantly during the grazing period.

A possible source of error when determining the incidence of an infection by serology is the delay between infection and seroconversion. By the serological methods applied in this study, antibodies are detected about 14-21 days after infection (Lundén, to be published). Since this period is relatively short in comparison with the interval between the sampling occasions, this delay will cause a serious bias only if exposure to infectious organisms is limited to the weeks just before or after sampling.

Regarding the 32 lambs found seropositive after their first grazing period, neither colostral antibodies nor congenital infections are likely explanations for their seroreactivity. The serological status of their dams indicates that only one of the 32 lambs was likely to have been congenitally infected, and maternally derived colostral antibodies are not detectable 3 months after birth (Waldeland 1977c). The seasonality of primary $T$. gondii infection observed in this study was consistent with the results of an earlier Swedish investigation comprising 704 sheep from 54 flocks in different parts of the country. Then, serological analysis of paired samples collected at tupping and lambing showed an incidence rate of only $0.7 \%$, while calculations based on seroprevalence in different age groups indicated an an- nual seroconversion rate of approximately $10 \%$ (Lundén et al. 1992). In Norway, however, Waldeland (1977b) observed the contrary, namely a higher incidence of infection during winter. This was assumed to be due to a heavier contamination of the fields close to the farms, where the sheep were kept in the winter, than on the more distant pastures grazed during summer. In the present investigation, the sheep were kept indoors during winter, which is common practice in Sweden. In accordance with the low incidence of primary infection detected during the gestation period, no reproductive losses attributable to toxoplasmosis were observed. The 5 ewes that gave birth to healthy lambs despite seroconversion during the indoor period probably acquired the infection before mating, or late in pregnancy when the risk of observable fetal damage is slight (Dubey \& Towle 1986).

The analyses of influence of persistent $T$. gondii infection on productivity performance revealed a tendency toward lower birth weights in lambs born to chronically infected ewes. Considering the apparently asymptomatic course of persistent infection in sheep (Dubey \& Towle 1986), this was an unexpected finding. Since many factors may influence lamb weights, it is not unlikely that circumstances not considered in this study could have been responsible for the observed effect. Therefore, to draw any firm conclusion, further studies would be needed. However, this possible effect of $T$. gondii infection, if not greater than observed here, is not likely to be of any practical or economical consequence, especially since the difference in lamb weight did not persist until weaning.

To prevent reproductive losses due to $T$. gondii infection it is of interest to identify potential sources of infection. It is generally believed that under natural conditions, strict herbivores such as sheep become infected by 
ingesting oocysts (Dubey and Towle 1986). In investigations of flocks with overt toxoplasmosis, pastures (Waldeland 1977b, Faull et al. 1986), grain (Plant et al. 1974) and silage (Waldeland 1977a) contaminated with cat feces have been found to be the likely sources of infection. In the present investigation detailed studies on possible sources of infection were not performed. Nevertheless, the results presented indicate that the main source was contaminated pastures, though infection during the indoor period also occurred.

\section{Acknowlegements}

The technical assistance of Ms. Britt-Louise Ljungström is greatly appreciated. We are also grateful to Mr. Jan Gosselman and Ms. Ingrid Falk for their assistance and helpfulness. This work was supported financially by the Swedish Foundation for Sheep Research.

\section{References}

Blewett DA: The epidemiology of ovine toxoplasmosis. I. The interpretation of data for the prevalence of antibody in sheep and other host species. Br. vet. J. 1983, 139, 537-545.

Desmonts G, Remington JS: Direct agglutination test for diagnosis of Toxoplasma infection: Method for increasing sensitivity and specificity. J. clin. Microbiol. 1980, 11, 562-568.

Dubey JP, Towle A: Toxoplasmosis in sheep. A review and annotated bibliography. C.A.B. International, Farnham Royal, UK, 1986.

Faull WB, Clarkson MJ, Winter AC: Toxoplasmosis in a flock of sheep: some investigations into its source and control. Vet. Rec. 1986, 119, 491-493.

Frenkel JK, Ruiz A, Chinchilla M: Soil survival of Toxoplasma oocysts in Kansas and Costa Rica. Amer. J. trop. Med. Hyg. 1975, 24, 439-443.

Lundén A, Carlsson U, Näslund K: Toxoplasmosis and border disease in 54 Swedish sheep flocks. Seroprevalence and incidence during one gestation period. Acta vet. scand. 1992, 33, 175-184.

Näsholm A, Danell $\overparen{O}$ : Growth and mature weight of
Swedish finewool landrace ewes. Acta agric. scand. 1990, 40, 71-81.

Plant JW, Richardson N, Moyle GG: Toxoplasma infection and abortion in sheep associated with feeding of grain contaminated with cat faeces. Aust. vet. J. 1974, 50, 19-21.

SAS Institute Inc.: Users guide: Statistics. Cary, N.C. USA, 1985, pp. 891-996.

Uggla A, Hjort M: A serological study on the prevalence of Toxoplasma gondii in meat-producing animals in Sweden. Acta vet. scand. 1984, 25, 567-576.

Waldeland H: Toxoplasmosis in sheep. Epidemiological studies in flocks with reproductive loss from toxoplasmosis. Acta vet. scand. 1977a, 18, 91-97.

Waldeland $H$ : Toxoplasmosis in sheep. Long-term epidemiological studies in four breeding flocks. Acta vet. scand. $1977 \mathrm{~b}, 18,227-236$.

Waldeland H: Toxoplasmosis in sheep. Influence of various factors on the antibody contents. Acta vet. scand. 1977c, 18, 237-247.

\section{Sammanfattning}

Långtidstudie av förekomst och betydelse av Toxoplasma gondii i en svensk fårbesättning.

Under 6 år undersöktes en svensk fårbesättning serologiskt avseende förekomst av Toxoplasma gondii-infektion. Besättningen var belägen i Uppland och bestod av 165-249 avelstackor, varav $20-35 \%$ var yngre än 1 år. Tackorna slaktades som regel vid 5 års ålder. Fåren var uppstallade från oktober till april, och lammade i mars och april. Serumprover togs från samtliga tackor 2 gånger om året, först på våren strax före betesläppning och sedan efter installning på hösten. Proverna analyserades avseende förekomst av antikroppar mot $T$. gondii med ELISA. Andelen seropositiva djur varierade under de 6 åren från $10 \%$ till $45 \%$. Så gott som samtliga fall av serokonversion upptäcktes vid provtagning på hösten, vilket tyder på att fåren blivit smittade på betet. Effekten av $T$. gondii-infektion på lammvikt, kullstorlek, total lammvikt per tacka och tackvikt undersöktes också. Lamm födda av kroniskt infekterade tackor hade något lägre födelsevikter än lamm födda av oinfekterade tackor. Vid avvänjningen påvisades dock ej någon skillnad i produktionsresultat.

(Received December 29, 1993; accepted June 7, 1994).

Reprints may be requested from: A. Lundén, Department of Parasitology, National Veterinary Institute, P. O. Box 7073, S-750 07 Uppsala, Sweden. 
